\title{
Synthesis and Identification of some Benzoxazole Derivatives via Mannich Reaction
}

\author{
Asmaa H. Sultan \\ Department of Chemistry/ College of Science/ University of Mosul
}

(Received 12/3/2013;Accepted 26/6/2013)

\begin{abstract}
The p-Hydroxybenzyldehyde is one of the aromatic compounds which contains two important functional groups $(\mathrm{OH}, \mathrm{CHO})$. In this work, the p-hydroxybenzyldehyde has been introduced into different reactions. The first one involves the synthesis of ether via Williamson reaction, in which p-hydroxybenzyldehyd reacts with chloroacetic acid to afford compound (1), then compound (1) in presence of sodium bicarbonate gives the anion (2). Which reacts with propargyl bromide to give the acetylenic compound (3). The compound (3) in turn reacts with secondary amine via Mannich reaction to give the acetylenic amines(4a-f). Finally, the compounds (4a-f) undergo reaction with o-amino phenol to give benzoxazole derivatives (5a-f). The structure of synthesized compounds had been elucidated by the available physical and spectral data.
\end{abstract}

Keywords: Mannich reaction, benzoxazole, p-hydroxybenzyldehyde, acetylenic amines.

\section{تخضير وتشخيص بهض مشقل البنزوسازط بلستخدلم غالل مالنخ}

\section{ll}

يعد البارا هيدروكسي بذزالديهايد من المركبلت الاروماتية المهمة في الكيمياء العضوية لاحتوائه عل ق مجم -وعتين

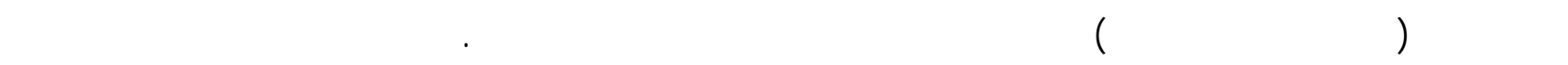

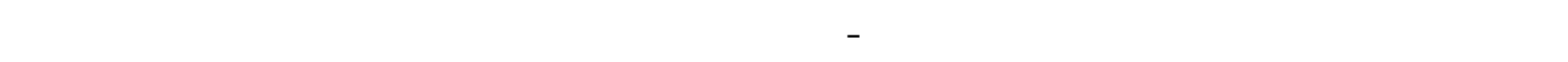

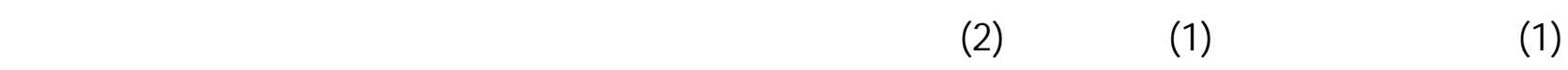

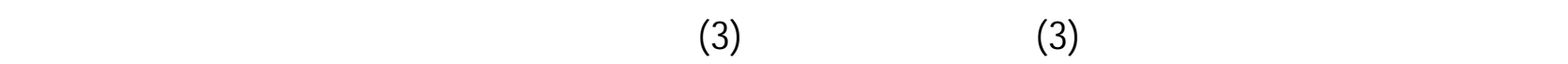

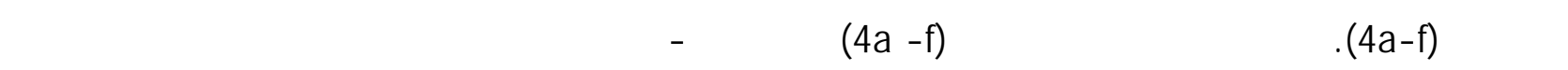
(5a-f)

الكالمال الدالة: قاعل مانخ، بذزوكسازول، بارا -هيدروكسي بنزالديهايد، المينات الاستيلينية.

\section{INTRODUCTION}

The five membered hetero cyclic compounds attracted a significant interest in medical, pesticide chemistry, polymer and material science (Annji et al., 2008), benzoxazole is known to possess an antibiotic effect (Evens et al., 1979) antiviral activity (Amidon et al., 2005), anticancer effect (Carturk et al., 2004), and antimicrobial activity (Agarwal, 2005).

Mannich reaction involves reaction of compounds containing active hydrogen with formaldehyde and amminonia, primary or secondary amine. Mannich reaction has been employed in the organic synthesis of neutral compounds such as peptides, nucleotides, antibiotics, and alkaloids (Hussin, 2009). Other applications were in agrochemicals such as plant growth, 
regulators (DaRosa, 2003). The Mannich products (acetylenic amine derivatives) were considered pharmaceutically active compounds for possessing several biological activities such as antispasmodic (Sheat and Ali, 2005), hypertensive (Sheat and Dawood, 2005) anticancer (AlIraqi and Yahya, 2009), and antibacterial activities (Sheat and Saeed, 2006).

\section{EXPERIMENTAL}

Melting points were determined using electrothermal 9300 melting point apparatus and are uncorrected. The IR spectra were recorded on pye-Unicam SP1100 spectraphotometer as (KBr) disc. UV spectra were recorded on Shimadzu (UV-160) UV-visible spectrophotometer using $\mathrm{CHCl} 3$ as a solvent.

\section{Preparation of 2-(4-formyl phenoxy) acetic acid (1) (Vishnoi, 1982):}

A solution of sodium $(0.3 \mathrm{~g})$ in absolute ethanol $(25 \mathrm{ml})$ was cooled then parahydroxybenzaldehyde ( 0.033 mole, $5 \mathrm{gm})$ and $(0.048$ mole, $8 \mathrm{gm})$ chloroacetic acid were added slowly. The reaction mixture was refluxed with stirring for $3 \mathrm{hr}$, then cooled in an ice-bath. The formed precipitate was filtered off, washed with ethanol and recrystallized from ethanol to give white crystals of $70 \%$ yield and mp $(180-182){ }^{\circ} \mathrm{C}$. The IR spectrum of compound (1) showed the following characteristic absorption band $\mathrm{cm}^{-1}$ : $1238(\mathrm{C}-\mathrm{O}-\mathrm{C})$, and $1723(\mathrm{C}=\mathrm{O})$ acid, $1675(\mathrm{C}=\mathrm{O})$ aldehyde.

\section{Preparation of sodium 2-(4-formyl phenoxy) acetate (2) (Saeed, 2010):}

The compound (1) (0.03 mole) was dissolved in an aquous solution of sodium bicarbonate $(0.03$ mole, $5 \mathrm{gm})$ in $(20 \mathrm{ml})$ of water. The solution was evaporated to dryness to obtain a white powder of compound (2).

Preparation of propargyl 2-(4-formyl phenoxy) acetate (3) (Saeed, 2010):

To a solution of the compound (2) $(0.02 \mathrm{~mole})$ in water $(20 \mathrm{ml})$, propargyl bromide $(0.02$ mole, $20 \mathrm{ml})$ was added. The mixture was heated on water bath at $\left(70-80{ }^{\circ} \mathrm{C}\right)$ for 2 hours with stirring. After cooling, cold water $(40 \mathrm{ml})$ was added with stirring and the oily product was changed to a precipitate. The precipitate was filtered off, washed with cold water and dried, then recrystallized from benzene to afford brown crystals of $66 \%$ yield and $\mathrm{mp}\left(58-60^{\circ} \mathrm{C}\right)$. The spectral data of compound (3) showed the following characteristic absorption bands $\mathrm{cm}^{-1}: 1677$ ( $\mathrm{C}=\mathrm{O}$ aldehyde), $2123(\mathrm{C} \equiv \mathrm{C}) 3150(\equiv \mathrm{C}-\mathrm{H}) 1761 \quad(\mathrm{C}=\mathrm{O}$ ester $)$. The $\mathrm{UV}$ spectrum showed $\lambda_{\max }$ at $256 \mathrm{~nm}$.

Preparation of 2-(4-formylphenoxy)-4-amino-2-butynyl acetate derivatives (4a-f) (Sheat and Saeed, 2006):

\section{General method (Mannich reaction) (Hussin,2009)}

A mixture of paraformaldehyde $(0.001$ mole, $0.9 \mathrm{~g})$ and appropriate secondary amine $(0.015$ mole) in absolute ethanol $(10 \mathrm{ml})$ was refluxed till clear solution was obtained. The acetylenic compound (3) $(0.04$ mole, $0.59 \mathrm{~g})$ in absolute ethanol $(10 \mathrm{ml})$ was added to the first reaction mixture and the resulted mixture was refluxed for $2 \mathrm{hr}$. The mixture was concentrated by evaporation of the solvent and the residue was filtered off and recrystallized from petroleum ether $\left(80-100^{\circ} \mathrm{C}\right)$ to give the desired compounds (4a-f) (Table 1). 


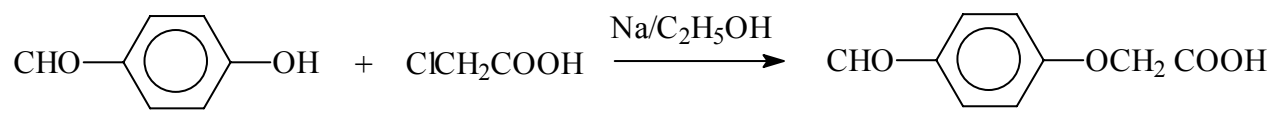

(1) $\downarrow \mathrm{NaHCO}_{3}$<smiles>C#CCOC(=O)COc1ccc(C=O)cc1</smiles>

(3)
$\mathrm{CHO} \longrightarrow-\mathrm{OCH}_{2} \mathrm{COOCH}_{2} \mathrm{C} \equiv \mathrm{C}-\mathrm{CH}_{2}-\mathrm{N}_{\mathrm{R}}^{-\mathrm{R}}$

(4a-f)<smiles>Nc1ccccc1O</smiles>
$\mathrm{NaHSO}_{3}$

Dimethyl formamide

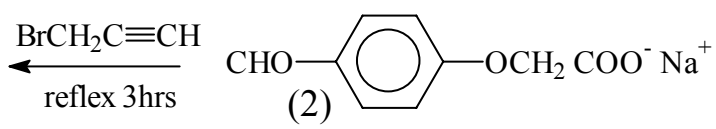

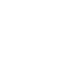




\section{Preparation of benzoxazoline derivatives (5a-f) (Gupta, 2011):}

To a stirred solution of the compounds (4a-f) $(0.011$ mole) in ethanol, sodium bisulfite $(0.0023$ mole, $5 \mathrm{~g})$ was added at room temperature. Then a solution of o-aminophenol $(0.0023$ mole, $5 \mathrm{~g})$ in dimethylformamide $(20 \mathrm{ml})$ was added and boiled under reflux for $3 \mathrm{hr}$. The reaction mixture was poured on an ice cold water $(20 \mathrm{ml})$ and the precipite formed was filtered off and recrystallized from ethanol. The physical and spectroscopic data of synthesized compounds (5a-f) were listed in (Table 2).

Table 2: Physical and spectral data of compounds (5a-f)

\begin{tabular}{|c|c|c|c|c|c|c|}
\hline \multirow{2}{*}{$\begin{array}{c}\text { Compd. } \\
\text { No. }\end{array}$} & \multirow{2}{*}{ Yield \% } & \multirow{2}{*}{ m.p. ${ }^{\circ} \mathbf{C}$} & \multicolumn{3}{|c|}{ IR (KBr)vem ${ }^{-1}$} & \multirow[t]{2}{*}{$\begin{array}{c}\mathrm{UV}\left(\mathrm{CHCl}_{3}\right) \\
\lambda_{\max }, \mathrm{nm} \\
\end{array}$} \\
\hline & & & $\mathbf{C}=\mathbf{N}$ & $\begin{array}{l}\text { C-O-C } \\
\text { Asy, sy }\end{array}$ & $\mathrm{C} \equiv \mathrm{C}$ & \\
\hline $5 \mathrm{a}$ & 55 & dec. 200 & 1559 & $\begin{array}{l}1246 \\
1166\end{array}$ & 2141 & 329 \\
\hline $5 b$ & 42 & $215-217$ & 1563 & $\begin{array}{l}1276 \\
1182 \\
\end{array}$ & 2125 & 320 \\
\hline $5 c$ & 30 & dec. 180 & 1558 & $\begin{array}{l}1247 \\
1167\end{array}$ & 2123 & 325 \\
\hline $5 d$ & 60 & dec. 132 & 1565 & $\begin{array}{l}1270 \\
1173 \\
\end{array}$ & 2132 & 315 \\
\hline $5 e$ & 32 & $200-203$ & 1568 & $\begin{array}{l}1243 \\
1165\end{array}$ & 2150 & 310 \\
\hline $5 \mathrm{f}$ & 32 & $140-143$ & 1572 & $\begin{array}{l}1250 \\
1169\end{array}$ & 2152 & 326 \\
\hline
\end{tabular}

\section{RESULTS AND DISCUSSION}

The synthetic route in this research was illustrated in scheme 1.The IR spectrum of compound (1) showed characteristic absorption bands at the region: $3060 \mathrm{~cm}^{-1}$ for the $\mathrm{O}-\mathrm{H}$ bond stretching, $(2852,2918) \mathrm{cm}^{-1}$ for the aliphatic C-H stretching vibration, 1677 and $1724 \mathrm{~cm}^{-1}$ for the $\mathrm{c}=\mathrm{O}$ bond stretching of the formyl and carboxyl moieties, in addation to absorption bond at 1238 and $1053 \mathrm{~cm}^{-1}$ for the asy. and sy. c-o-c bond. The UVspectrum showed $\lambda_{\max }$ at $(254) \mathrm{nm}$. The other supporting evidence for this compound is the negative ferric chloride test.

To synthesize the ester (3), the carboxylic acid was treated with sodium bicarbonate to produce the enolate anion (2) which upon treatment with propargyl bromide afforded the propargyl ester (3). The IR spectrum of compound (2) showed a strong band at 1240 and 1163 $\mathrm{cm}^{-1}$ for the asy. And sy. c-o-c bond stretching respectively. The UV spectrum of compound (2) showed $\lambda_{\max }$ at $(256) \mathrm{nm}$.

The spectrum of compound (3) showed characteristic absorption bands: 1761 and $1677 \mathrm{~cm}^{-1}$ for the ester and aldehydic $\mathrm{c}=\mathrm{O}$ bond stretching, at $2123 \mathrm{~cm}^{-1}$ for the $\mathrm{c} \equiv \mathrm{c}$ bond stretching and at $3250 \mathrm{~cm}^{-1}$ for the $\equiv \mathrm{C}-\mathrm{H}$ bond stretching. The UV spectrum of compound (3) showed $\lambda_{\max }$ at (256) nm due to the (n $\longrightarrow \pi^{*}$ ) electronic transition.

The other supporting evidence for the formation of this compound is the positive tollens test for the terminal acetylenic compounds. The acetylenic compound (3) was converted to the Mannich base by its reaction with secondary amines in presence of paraformaldehyde. The structure investigation of the synthesized acetylenic amines derivatives (4a-f) was achieved according to their physical and spectroscopic data (IR, UV) (Table 1).

The IR spectra of compounds (4a-f) showed a strong absorption band for esteric as indicated in (Table 1) showed a strong absorption band for esteric $\mathrm{c}=\mathrm{O}$ at $(1755-1727) \mathrm{cm}^{-1}$, weak band for 
$\mathrm{C} \equiv \mathrm{C}$ at $(2154-2125) \mathrm{cm}^{-1}$, the IR spectra indicated the disappearance of $\equiv \mathrm{C}-\mathrm{H}$ bond stretching at $3150 \mathrm{~cm}^{-1}$ (Parikh,1974).

The UV spectra of compounds (4a-f) showed a bathochromic shift in $\lambda \max (250-282) \mathrm{nm}$ as compared with compound (3) ( $\lambda \max 256 \mathrm{~nm})$.

Other supporting evidences are that the acetylenic hydrogen in compound (3) showed positive Tollens test which become test negative in Mannich products (4a-f)

The aldehydic group can be used to synthesize the benzoxazoline derivatives (5a-f) by its reaction with o-amino phenol. The formation of these compounds was proceeded according to the following suggested mechanism.

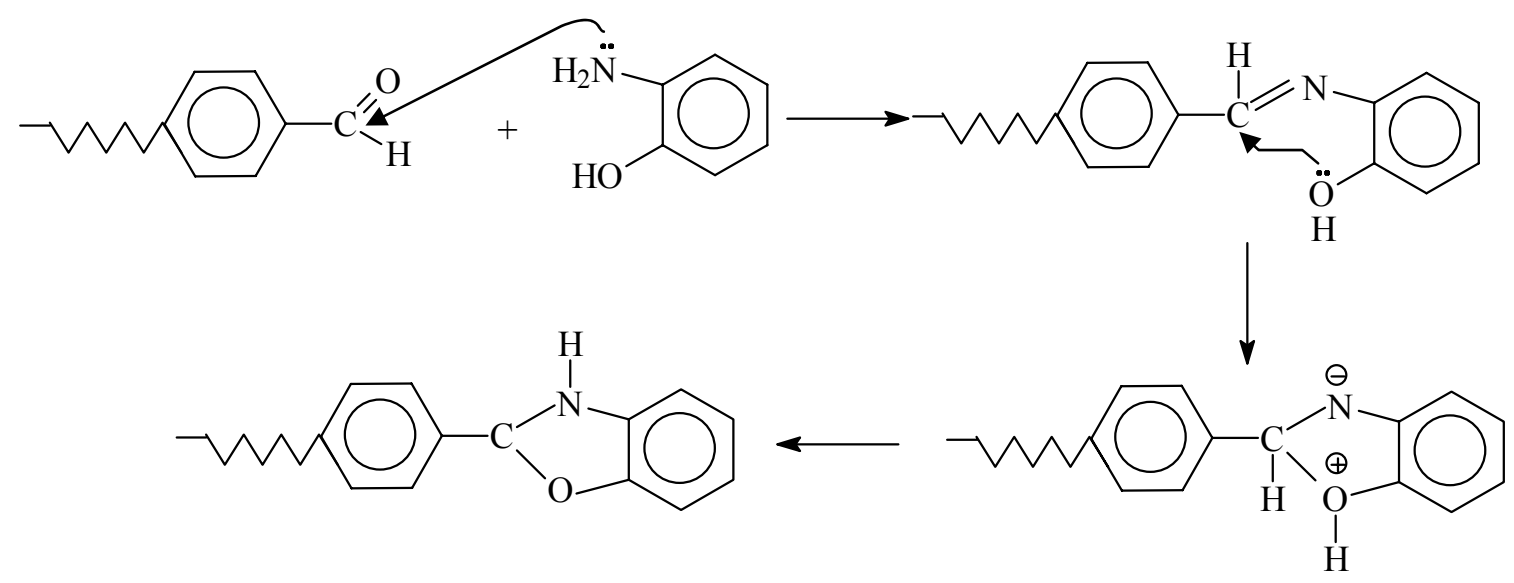

IR spectra of compounds (5a-f) as indicated in Table (2) show strong absorption band for benzoxazole $\mathrm{C}=\mathrm{N}$ at $(1558-1572) \mathrm{cm}^{-1}$. The disapperance of the absorption bands for the aldehydic $\mathrm{C}=\mathrm{O}$ band stretching in the range of $(1715-1695) \mathrm{cm}^{-1}$ give a good indication for the formation of the oxozoline ring in compounds (5a-f).

The UV spectra of compounds (5a-f) showed bathochromic shift $\lambda \max$ at(310-329) $\mathrm{nm}$ due to the conjugation effect on electronic transition $\left(\mathrm{n} \longrightarrow \pi^{*}\right)$ in the synthesized compounds (5a-f) as shown in Table (2) (Parikh,1974).

\section{REFERENCES}

Agarwal, A.; Srivastava, K.; Puri, S.K.; Chauhan, P.M.S. (2005). Synthesis of 2,4,6-trisubstituted triazines as antimalarial agents. J. Med. Chem., 48(3), 5570-5579.

Al Iraqi, M.; Yahya, A.M. ( 2009). Synthesis of N-aryl-P-toluene sulfonamide compounds. J. Raf. Sci. 20(4), 58-68.

Annji, M.; Galisudhakar, R.; Venkatapuram, P.; Konda, M. (2008). Synthesis of symmetrical and unsymmetrical 1,3,4-oxadiazoles and their interconversion to 1,3,4-thiadiazoles and 1,2,4triazoles. Arkivoc., 48(6) 1551.

Amdion, L.; Drach, J.; Song, M.: Vig, B.; Lorenz, P. (2005). Amino acid ester Prodrugs of the antiviral agent 2-bromo-5,6-dichloro-1-( $\beta$-d-ribofuranosyl) benzimidazole as potential substrates of hPEPT1 transporter. J. Med. Chem., 46(9), 1274-1277.

Carturk, N.U.; Senser, E.; Yildiz, L. (2004). Synthesis and structure-activity relationships of new antimicrobial active multi-substituted benzoxazole derivatives. J. Med. Chem., 3, 446-449.

Evans, D.A.; Taber, T.B.; Kleschick, W.A. (1979). Polyether antibiotics synthesis, total synthesis and absolute configuration of the ionophore. J. Am. Chem. Soc., 101(5), 6788-6791.

Hussin, H.Y. (2009). Synthises of some acetylenic amines derivetives by Mannich reactinon. J. Raf. Sci., 20(4), 52-54. 
DaRosa, F.; Rebelo, A.F.; Nascimen, M.G. (2003). Synthesis of new indolecarboxylic acids related to the plant hormone Indoleacetic acid IAA. J. Braz. Chem. Soci., 14, 11.

Sheat, M.A.; Ali, S.R. (2005). Synthesis and study of acetylenic amines derevitives from p-amino phenol. Nat. J. Chem., 22, 269-280.

Sheat, M.; Dawood, A.A. (2005). Preparation of some acetylene amine derivative of saccharine as expected biologically active agents. J. Edu. Sci., 15(2), 44-51.

Sheat, M.A.; Saeed, Z.F. (2006). Synthesis and study of acetylenic amines derevitives containing sulfonamide, $\beta$-naphthoxy and hippurate groups. Nat. J. Chem. 21, 53-62.

Parikh, V.M.(1974)."Absorption Spectroscopy of Organic Molecules" .addison Wesley publishing company ,Boston ,p 43,182.

Vishnoi, N.K. (1982). "Advanced practical organic chemistry". Vikas Publishing House PV, LTD, $364,375$.

Saeed, Z.F. (2010). Synthises of some acetylenic amino derevatives from salicylic acid. J. Edu. Sci, 3(23).

Vikas, S.; Vinod, D.G.; Kiran, R. (2011). Synthesis of novel dipodal-benzimidazole, benzoxazole and benzothiazole from Phatanyare cyanuric chloride: Structural, photophysical and antimicrobial studies. J. Sau. Chem. Soci., 13 july 2011. 